\title{
Pollution assessment of Ennore (India) creek using macrobenthos
}

\author{
Usha Natesan ${ }^{1}$, S Kalaivani ${ }^{1}$, G Kalpana ${ }^{1,2}$
}

\begin{abstract}
Natesan U, Kalaivani S, Kalpana G. Pollution assessment of Ennore (India) Creek Using Macrobenthos. J Environ Geol. 2017;1(1):9-16.

In the present study, the change in benthic community was identified in the coastal stretch from Ennore to Pulicat, total of 6 stations were identified to study benthic community. In order to understand the distribution of the benthic community structure with respect to macro fauna in the Buckingham canal benthic were collected from all the stations during high tide on Spring tide of each month from September 2004 to December 2005 from bed and bank. Higher nutrient concentration during summer coincides with high
\end{abstract}

density of Polycheates and Molluscs and vice versa during monsoon season. Salinity is also an important factor for macro fauna distribution and growth. Salinity is high during pre-monsoon and summer which resulted in high production. From the Abundance and Biomass correlation it is inferred that Station 2 and 4 are grossly polluted. Stations 1, 3 and 5 are moderately polluted and Station 6 is less polluted.

Key Words: Macrobenthos, PRIMER, Ennore, Biomass, Abundance and bio-env

an outlet for the excess water from the Poondi Reservoir. The Ennore Creek flows west to east, and opens into the Bay of Bengal at Ennore. Buckingham canal runs parallel to the east coast of India, form Kakinada in the north till Pondicherry in the south. This canal cuts perpendicularly the Ennore Creek, south to north, and enters the vast Pulicat Lagoon in the north at the Kotaikuppam Lock. It then is confluent with the Pulicat Lagoon, for about $1 \mathrm{~km}$ and then emerges onto the Sriharikota Island at the Moosamani Lock, and runs parallel along the western margin of the Sriharikota Island. Between Ennore and Pulicat, the canal spreads out into vast open stretches of shallow waters. There is a second inlet to the Buckingham Canal around $21 \mathrm{~km}$ from the Ennore Creek, but this tidal inlet is closed permanently due to a natural sand bar formation. The climate at Ennore is tropical with high humidity. The coastal area is normally governed by land and sea breezes. The region experiences two distinct monsoons viz., the Southwest (SW) monsoon from June to September and Northeast (NE) monsoon from October to December. SW monsoon is normally temperate in strength. NE monsoon is rather more variable in speed and direction, but the strength is moderate, between $\mathrm{N}$ and NE for long spells over most of the area when well established. In the present study, the change in benthic community was identified in the coastal stretch from Ennore to Pulicat, total of 6 stations were identified to study benthic community. In order to understand the distribution of the benthic community structure with respect to macro fauna in the Buckingham canal benthic were collected from all the stations during high tide on Spring tide of each month from September 2004 to December 2005 from bed and bank.

\section{MATERIALS AND METHODS}

Surface sediment samples were collected at six stations in the Buckingham Canal with the help of Petersen grab sampler covering an area of $0.1 \mathrm{~m}^{2}$. In order to understand the distribution of the benthic community structure with respect to macrofacuna in the Buckingham canal, from six stations during high tide on Spring tide of each month from September 2004 to December 2005. Samples were collected using a fishing boat. From the 25 $\mathrm{km}$ stretch of study area from Ennore Creek to Pulicat mouth, based on the various environmental stresses 6 sampling stations were identified as follows:

Station 1 - near Ennore Creek mouth where coolant water from the thermal power plant is discharged.

Station 2 - south of Ennore Creek representing the discharges from various industries.

Station 3 - in the Buckingham canal $5 \mathrm{~km}$ away from Station 2.

Station 4 - in the Buckingham canal near aquaculture farms and adjacent to the second inlet.

Station 5 - $1 \mathrm{~km}$ after the second inlet.

Station 6 - near the Pulicat Lagoon inlet where the environmental stress is comparatively less.
The Ennore creek is located approximately $24 \mathrm{~km}$ in the northeastern part of Chennai City, Tamil Nadu, India at the coast of Bay of Bengal (Figure 1). The Ennore Creek is the estuary or the mouth of the river Kortalliyar, which is 
The larger organisms were handpicked immediately and then sieved through $0.5 \mathrm{~mm}$ mesh screen. The labelled container and fixed in $5 \%$ formalin. The organisms were stained with Rose Bengal solution $(0.1 \mathrm{~g}$ in $100 \mathrm{~mL}$ of distilled water) for enhanced visibility during identification. The samples were then preserved in $75 \%$ alcohol for further identification. In the macrofauna three groups viz., polycheates, crustaceans and molluscs were considered for analyses. All the specimens were sorted, enumerated and identified to the advance level possible with the consultation of available literature (19-24). The total biomass of benthic macrofauna collected in the present study was estimated by wet weight method. In molluscs, the shells were sorted to size (mm-group) and the meat was removed from the shells before weighing. The shells were opened by immersion in boiling water (Table 1).

\section{Statistical analysis}

The statistical analysis was done using the PRIMER (Plymouth Routines in Multivariate Ecological Research) software, which has the scope for analysing the data arising in community ecology and environmental science that is multivariate in character. The primitive abundance data of the macrobenthic fauna communities, after its transformation and standardization via the calculation of the fourth root, was analyzed by hierarchical clustering (using group-average linkage method) and nonmetric multidimensional scaling (NMMDS) based on the measurement of Bray-Curtis similarity. The BioEnv procedure simply selects the combination of environmental variables which maximises $\rho$, i.e. 'best explains' the biotic assemblage structure. More generally, we shall refer to this as the BEST (Bio-Env + STepwise) procedure, to include also the situations in which calculation of all combinations of explanatory variables is prohibitive, and a stepwise algorithm, employing forward-stepping and backward-elimination as in stepwise regression (25), is used to search for the optimal $\rho$ (26). The approach adopted is first to analyse the biotic data and then to check how better the environmental data matches the community structure. The intuitive premise adopted here is that if the suite of environmental variables (water quality parameters are Temperature, Salinity, DO, TN and the parameters viz., $\mathrm{pH}$, Silt, Sand, TOC, TN and TP play a role with respect to the sediment) responsible for structuring the community were known, then samples having rather similar values for these variables would be expected to have rather similar species composition, and an ordination based on this abiotic information would group sites in the same way as for the biotic plot.

\section{RESULTS AND DISCUSSION}

\section{Water quality of Ennore creek}

\section{pH}

$\mathrm{pH}$ varies from 6.5 to 8.9. Extensive buffering capacity of the sea water allows only little $\mathrm{pH}$ changes to be pronounced normally in enclosed portions whereas biological activity can cause sizeable variations. At Stations 4, 5 and 6 surface waters show high pH during September to November 2004. This may be due to the effect of the monsoon. When compared to the near bottom samples the surface waters experience a slight higher $\mathrm{pH}$ at Station 1 during January and February 2005. A similar observation is noted at Station 2 during February 2005. This may be due to the effect of Tsunami which resulted in the dilution of the canal waters. Otherwise the $\mathrm{pH}$ variations between surface and bottom are less significant. Comparatively low $\mathrm{pH}$ at Stations 2 and 4 may be due to the intense bacterial degradation of organic matter and less photosynthetic activity of algae. Low $\mathrm{pH}$ values in Station 2 could be attributed to the increase in Carbon dioxide resulting from a rise in temperature due to the coolant water discharge. Higher $\mathrm{pH}$ values are recorded at Stations $1,3,5$ and 6 . The relatively high $\mathrm{pH}$ may be attributed to the intense photosynthetic activity of algae as evident by high phytoplankton population and DO.

\section{Temperature}

The surface water temperature in the stations varies from $29.5^{\circ} \mathrm{C}-39.5^{\circ} \mathrm{C}$ and near bottom samples shows an average $10^{\circ} \mathrm{C}$ reduction than the surface waters. Station 1 records remarkably higher temperature with an average increase of $90^{\circ} \mathrm{C}$ compared to other stations. The consistent high temperature at Station 1 is due to the coolant water discharge from NCTPS. The recommended temperature for discharge into a water body is $320^{\circ} \mathrm{C}$. Except at Station 1, all the other Stations record less and similar temperatures. The high temperature around $32^{\circ} \mathrm{C}$ observed during April-June might be due to the influence of summer season, low flow, clear atmosphere, and high percentage of humidity, low air temperature and the absence of rainfall. The low temperature of $29.5^{\circ} \mathrm{C}$ observed during October-December might be due to the climatic changes, precipitation and a reduction in incoming radiation, and winds. Pre monsoon and post monsoon record moderate temperature.

\section{$\underline{\text { Salinity }}$}

The salinity values ranges from $15 \mathrm{ppt}$ to $34 \mathrm{ppt}$. A slight increase in salinity is observed in the near bottom samples than the surface samples in Stations 1 and 2. This variation is clearly portrayed during monsoon season which could be attributed to the fresh water mixing on the surface due to rainfall. In general, Station 2 records less salinity values (28ppt) which reduces further (15ppt) during monsoon due to the effect of industrial discharges. The tidal influence is very much pronounced in Station 2. During high tide, the salinity is more due to the large quantity of salt water that enters into the Canal from the sea. It is also seen that salinity decreases at Station 6 due to the influence of fresh water from Pulicat lagoon. Interestingly the increase in salinity in Station 5 can be attributed to the sea water seepage from the closed second inlet. Seasonally there is not much fluctuation in salinity during the period of study, but still slight variation is seen. In summer, excess evaporation, neritic water dominance and lack of freshwater inflow lead to higher salinity values than the other seasons. Large amount of sea water mixing due to Tsunami is evident from the higher salinity observed at Stations 1 and 2 during January 2005.

\section{Species composition of macrobenthos}

Macroscopic organisms and other bottom dwelling invertebrates are primary food resources for fishes and other large animals (27). They also serve as sensitive indicators of overall aquatic ecosystem health. Table 2 displays the list of macrofauna identified in the study area. The polycheates, crustaceans and molluscs are identified to species level and where identification was difficult it is done to the lowest practical level. In the Buckingham Canal, about 65 genera and 84 species of macrofauna are identified, consisting of schyphozoa (2 species), polycheates (24 species), Crustaceans (15 species), molluscs (42 species) and echinodermata (1 species). Since polycheates, crustaceans and molluscs forms the major classes in the Canal, only these

TABLE 1

Sediment composition.

\begin{tabular}{|c|c|c|c|c|c|c|c|c|c|c|c|c|c|c|c|}
\hline \multirow[t]{2}{*}{ Stn. } & \multicolumn{3}{|c|}{ Monsoon'04 } & \multicolumn{3}{|c|}{ Post Monsoon '04 } & \multicolumn{3}{|c|}{ Summer '04 } & \multicolumn{3}{|c|}{ PreMonsoon'05 } & \multicolumn{3}{|c|}{ Monsoon'05 } \\
\hline & Sand & Silt & Clay & Sand & Silt & Clay & Sand & Silt & Clay & Sand & Silt & Clay & Sand & Silt & Clay \\
\hline 1 & 90 & 10 & 0 & 91 & 9 & 0 & 88 & 12 & 0 & 89 & 11 & 0 & 91 & 9 & 0 \\
\hline 2 & 5 & 89 & 6 & 6 & 90 & 4 & 3 & 87 & 10 & 4 & 88 & 8 & 6 & 90 & 4 \\
\hline 3 & 6 & 75 & 19 & 7 & 76 & 17 & 4 & 73 & 23 & 5 & 74 & 21 & 7 & 76 & 17 \\
\hline 4 & 7 & 42 & 51 & 8 & 43 & 49 & 5 & 40 & 55 & 6 & 41 & 53 & 8 & 43 & 49 \\
\hline 5 & 17 & 31 & 52 & 13 & 32 & 55 & 9 & 29 & 62 & 10 & 30 & 60 & 18 & 32 & 50 \\
\hline 6 & 23 & 38 & 39 & 24 & 39 & 37 & 21 & 36 & 43 & 22 & 37 & 41 & 24 & 39 & 37 \\
\hline $1 a$ & 87 & 13 & 0 & 86 & 12 & 2 & 85 & 11 & 4 & 88 & 12 & 0 & 88 & 12 & 0 \\
\hline $2 a$ & 3 & 92 & 5 & 4 & 93 & 3 & 1 & 90 & 9 & 2 & 91 & 7 & 4 & 93 & 3 \\
\hline $3 a$ & 5 & 76 & 19 & 6 & 77 & 17 & 3 & 74 & 23 & 4 & 75 & 21 & 6 & 77 & 17 \\
\hline $4 a$ & 7 & 45 & 48 & 8 & 46 & 46 & 5 & 43 & 52 & 6 & 44 & 50 & 8 & 46 & 46 \\
\hline $5 a$ & 20 & 36 & 44 & 14 & 37 & 49 & 10 & 34 & 56 & 11 & 35 & 54 & 21 & 37 & 42 \\
\hline $6 a$ & 25 & 41 & 34 & 26 & 42 & 32 & 23 & 39 & 38 & 24 & 40 & 36 & 26 & 42 & 32 \\
\hline
\end{tabular}


TABLE 2

Occurrence of macrofauna species.

\begin{tabular}{|c|c|c|c|c|c|c|c|}
\hline & Scyphozoa & 22 & Nephthys polybranchia & 43 & Turbo bruneus & 66 & Distorsioreticulata \\
\hline 1 & Chrysoraquinquecirrha & 23 & Marphysagravelyi & 44 & Neritapolita & 67 & Bursa spinosa \\
\hline \multirow[t]{2}{*}{2} & Rhizostoma sp. & 24 & Sabellariaalocki & 45 & Neritaplicata & 68 & Haustellum haustellum \\
\hline & Polycheates & 25 & Sabellariacementarium & 46 & Littorniascabra & 69 & Murex ternispina \\
\hline 3 & Stenolepis japonica & 26 & Serpulavermicularis & 47 & Littornia undulate & 70 & Murex virgineus \\
\hline 4 & Amphinomerostrata & & Crustaceans & 48 & Littorniamelanostoma & 71 & Pleuroploca trapezium \\
\hline 5 & Chloeiaparva & 27 & Lepasanserifera & 49 & Turritellacolumnaris & 72 & Oliva oliva \\
\hline 6 & Alciopinaparasitica & 28 & Balanusamphitrite & 50 & Turritellaacutangula & 73 & Melampusceylonicus \\
\hline 7 & Tomopterishelgolandica & 29 & Balanusreticlatus & 51 & Turritellaattenuata & 74 & Pythia plicata \\
\hline 8 & Pelagobialongicirrata & 30 & Balanus variegates & 52 & Architectonia perspective & 75 & Cardita bicolor \\
\hline 9 & Ancistrosyllisconstricta & 31 & Alpheus malabaricus & 53 & Telescopium telescopium & 76 & Trachyxardiumasciaticum \\
\hline 10 & Glycera alba & 32 & Emerita asciatica & 54 & Certhideacingulata & 77 & MactraLaevis \\
\hline 11 & Lumbriconereis simplex & 33 & Dorippedorcipes & 55 & Cerithideaobusta & 78 & Meretrixmeretrix \\
\hline 12 & Lumbriconereislatreilli & 34 & Scylla serrata & 56 & Janthanaglobosa & 79 & Meretrixcasta \\
\hline 13 & Lumbriconereis impatiens & 35 & Scylla tranquebarica & 57 & Strombuslisteri & 80 & Marcia opima \\
\hline 14 & Diopatraneapolitana & 36 & Portunuspelagicus & 58 & Strombusmarginatus & 81 & Pernaviridis \\
\hline 15 & Cossura delta & 37 & Portunussanguinolentes & 59 & Tibia curta & 82 & Volachlamystranquebarica \\
\hline 16 & Scoloplosmarsupialis & 38 & Charybdis feriatus & 60 & Naticamacrochiensis & 83 & Crassotreamadrasensis \\
\hline 17 & Heteromastus similes & 39 & Ocypodeplatytarsus & 61 & NaticaTigrina & & Echinodermata \\
\hline 18 & Capitellacapitata & 40 & Ocypodemacrocera & 62 & Polinicesdidyma & 84 & Astropectenstelleroidea \\
\hline 19 & Aphrodite sp. & 41 & Lacteaannulipes & 63 & Polinicestumidus & & \\
\hline 20 & Ceratonereis costae & & Molluscs & 64 & Sinumneritoideum & & \\
\hline 21 & Perinereiscultrifera & 42 & Umboniumvestiarium & 65 & Tonnadolium & & \\
\hline
\end{tabular}
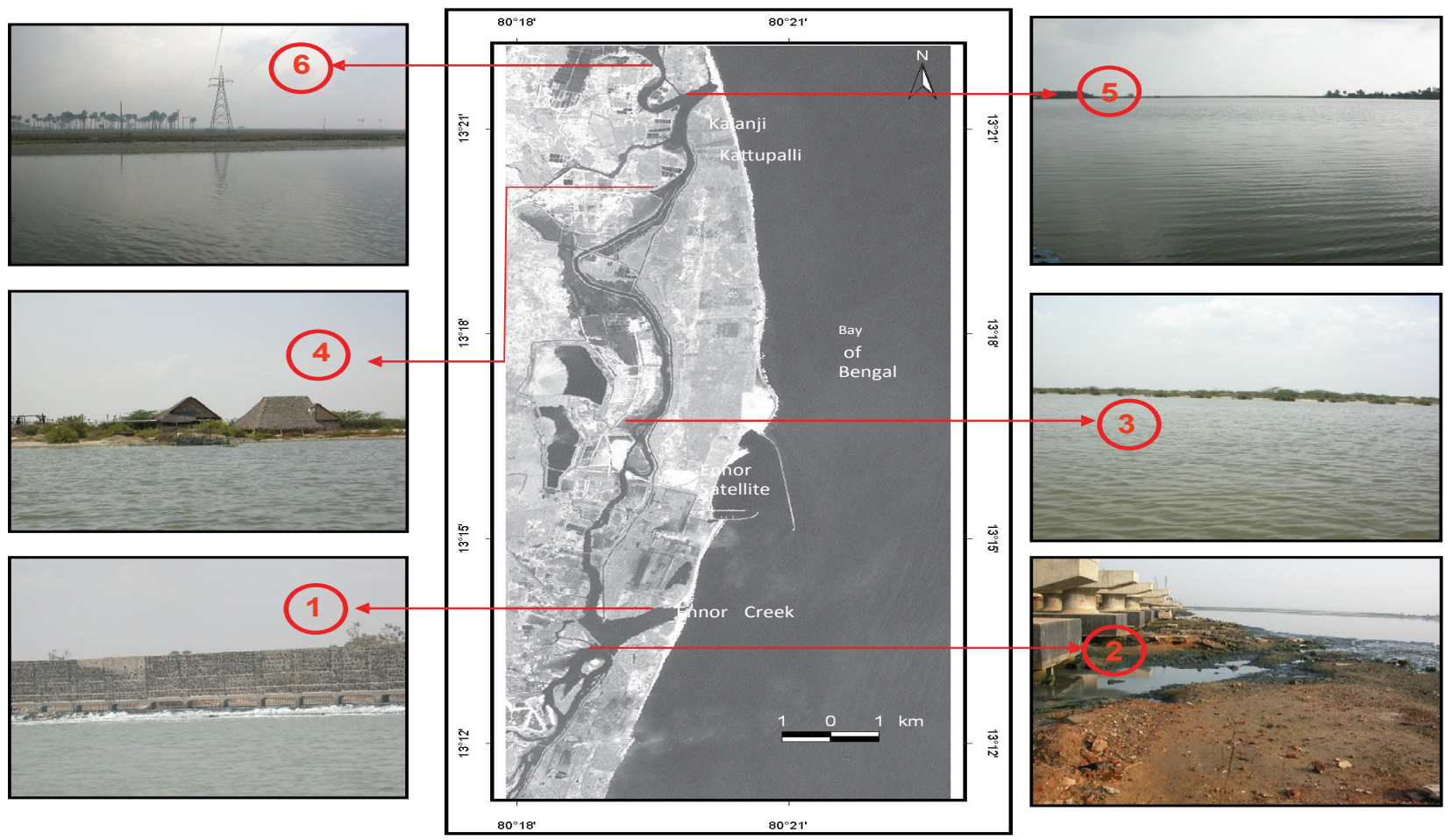

Figure 1) Study area with sampling stations.

groups are taken for detailed analyses. Species are grouped into taxonomic classes in order to provide a reasonably succinct interpretation of the data.

Table 2 also includes some of the off shore species recorded during tsunami. Amphinomerostrata are seen in Station 1 attached to logs and they are planktonic in nature. Janthanaglobosa that are usually found on the surface of oceanic waters were seen floating in the Canal waters during January 2005. Along with the above species Tonnadolium and Bursa spinosa are also found in the sediments of Station1. Chloeiaparva, Portunuspelagicus and Portunussanguinolentes are identified in Stations 1 and 5. In the beaches of Station 1, Ocypodemacrocera also referred as Red Ghost Crab is recorded during night. Polinicesdidyma are observed only in Station 5. Strombuslisteri, Tibia curta, Haustellum haustellumare found in Stations 5 and 6. Stenolepis japonica and Nephthys polybanchia are found distributed in the entire canal. The occurrence of all the above mentioned species are seen from January
2005 to March 2005, but after March 2005 their numbers declined. Only two species of Astropectenstelleroidea occurred during January 2005 at Station 6. These species should have entered the canal via the Ennore Creek and the Second tidal inlet near Station 5 at the Pulicat lagoon.

\section{Macrobenthic density}

Bhat and Neelakantan (28) described the environmental characteristics of an estuary fluctuate periodically depending on three seasons i.e. premonsoon, monsoon and post-monsoon. The post-monsoon is known for stable environmental condition and increasing benthic production. In present study, the seasonal variations in abundance and biomass followed a similar pattern with low values in monsoon and pre-monsoon. The Standing Crop of macrofauna with respective to different seasons is represented in Figure 2. Though there are seasonal fluctuations seen in the faunal 
Bed
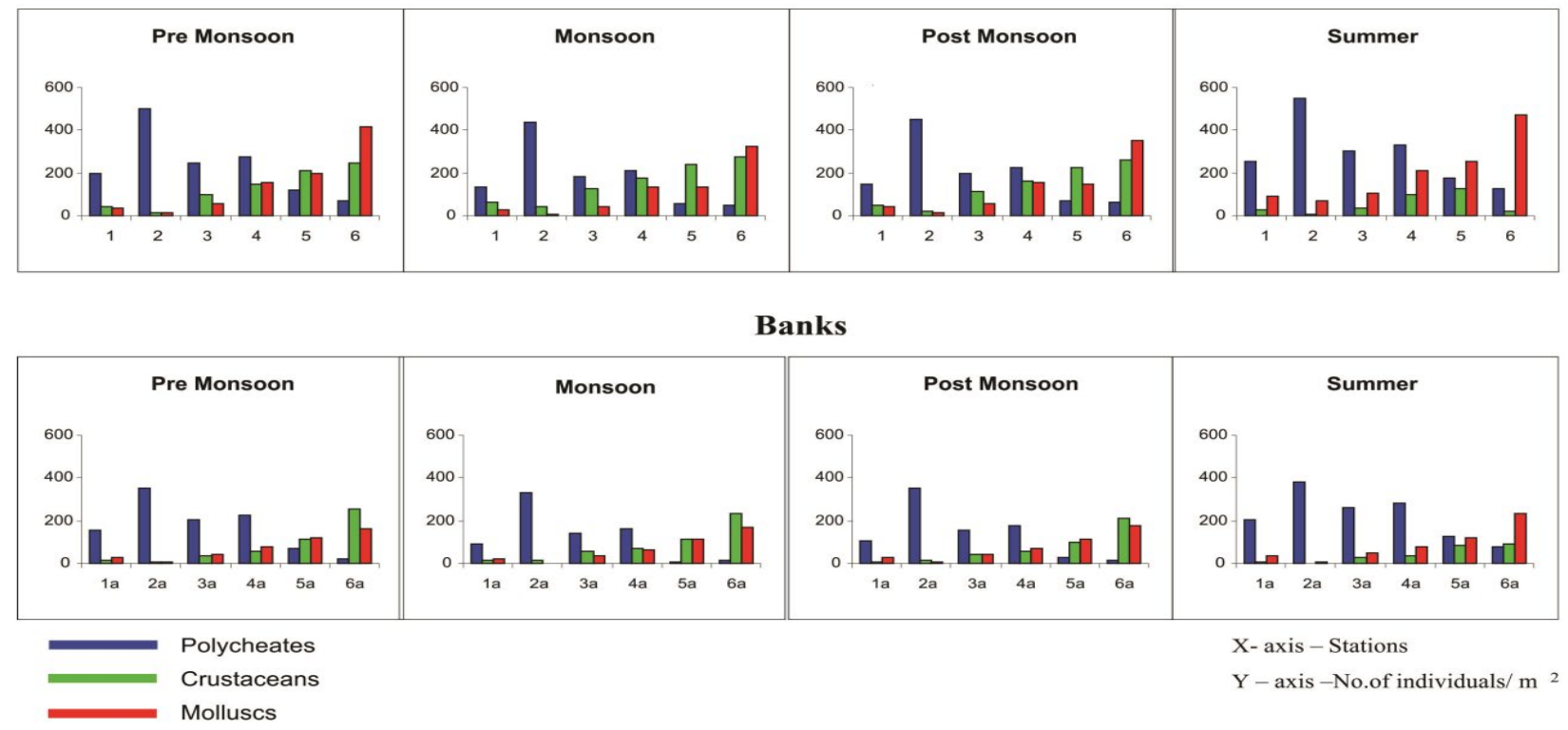

Figure 2) Standing crop of macro fauna groups.

densities, the variation is less pronounced. The maximum abundance in the bed and banks are observed in summer and it starts declining in the pre monsoon and relatively less in the monsoon season. Monsoon and post monsoon have similar abundance. The density of benthic seen during summer may be high because of the high salinity which favors the growth of molluscs. The reason for the decline of the numbers during monsoon and pre monsoon may be due to the absence of favorable conditions i.e., low salinity. Predation can regulate species abundance at multiple trophic levels (29)). Station wise density for benthic can be presented as Stations $6>2>4>$ $5>3>1$. This high abundance in Station 6 (Pulicat lagoon inlet) is due to the absence of any environmental stress. Here the highest density is seen during pre-monsoon, monsoon and post monsoon and summer has less density. On the other hand though at Station 2 (south of Ennore creek, where discharge of industrial effluents is seen) the stress is more, the density is high due to the domination of the polycheates that can tolerate the adverse environmental conditions present here. Station 1(mouth region where coolant water from thermal power plant is discharged) has the least abundance, the discharge of coolant water, causes the death of fauna in large numbers resulting in less density of benthic. At all the Stations and seasons it is clear that the bed illustrates higher abundance of fauna than the banks, due to the availability of high nutrients and favorable environmental conditions.

\section{Macrobenthic biomass}

Macrobenthic biomass is estimated for different species of all the three classes. Table 3 gives the total biomass of the three different classes of macrofauna. High biomass of the polycheates is seen at Station 2, followed by Station 4 . Least biomass of the polycheates is observed at Station 6. A vice - versa trend in biomass is observed in the cases of Crustaceans and molluscs. Low biomass is also recorded at Station 1 due to the increased temperature. Stations 3 and 5 have intermediate values of biomass, proving that the pollutants are getting transferred to these stations thus decreasing the biomass of the fauna. A decrease in biomass and population density from pre monsoon to monsoon and a gradual increase towards post monsoon and summer are observed at all the stations in the case of polycheates and molluscs, the trend followed that of salinity closely. This is another proof for the high biomass at Stations 5 and 6 conforming to the observations of (30-32). The decrease in salinity during monsoon may be one of the factors responsible for this observation. The Crustaceans demonstrates high abundance during monsoon and post monsoon and it gradually decreases during summer. Trends of abundance and biomass of the polycheates, crustaceans and the molluscs are identical. The monsoons of the two years follow a similar pattern. Though numerically less, the contribution towards biomass is more by the mollucs. This is due to the large size of the Molluscs which increase their body weight. Glyceraalba and Capitellacapitata are the two important polycheates contributing to the high biomass at Stations 2 and 4.

\section{Similarity between the stations}

The similarity between the stations based on macrofauna abundance is shown in Figure 3. Irrespective of the season, the abundance data is averaged and the similarity between the Stations are analysed for individual classes. At $90 \%$ similarity, the polycheates document four clusters. Stations 1, 2 and 6 cluster with their respective banks behave individually and Stations 3, 4 and 5 are linked together illustrating a single cluster. The dendogram of the crustaceans and the molluscs illustrate the formation of similar clusters. The Stations 1, 3, 4, 5 and 6 behave similarly. Station 2 due to the presence of anoxic conditions and various other environmental stresses behave differently and hence demonstrates an individual cluster.

\section{Discriminating species in macrofauna}

It is possible to discriminate species assemblages for each environmental stress in the study area through the routines implemented in PRIMER (SIMPER analysis). Table 4 explains the discriminating assemblages. Discriminating species differentiate one station from other. They are tolerant to the environmental conditions existing in that particular station. Based on the environmental stresses, Stations 1, 2, 4 and 6 were taken individually and Station 3 and 5 were considered together. SIMPER was also used to determine the degree of correlation of the samples with a community gradient. For all the species Average similarity (Av. Sim.) was divided by the ratio of Similarity and Standard deviation (Sim/SD), if the value ${ }^{3} 1$ then such species are identified as discriminating species.

Polycheates are found to be tolerant as it is observed in Station 2 owing to the organic enrichment and anoxic conditions. At Station 1, certain species of polycheates, species of the genera Balanus are found to withstand the adverse temperature. Though species of all the three classes discriminate Stations 3 and 5, the polycheates species constitute the majority, proving that these Stations are also polluted. This is due to the fact that the pollutants from Stations 2 and 4 get transported to the above Stations. At Station 6, species of Crustaceans and molluscs form the discriminating species. The contribution percentage of Dioptaraneapolitana is the highest in Station 1 due to high salinity. The percentage contribution Capitellacapitata is the maximum at Station 2, proving that the abundance of the polycheates species contributes to the high abundance found. Similar observation is seen in Station 4. Cossura delta contributes the maximum abundance at Stations 3 and 5. Station 6 being less polluted, Cerithideacingulatais found in large numbers, increasing the percentage contribution.

The relation between abundance and biomass is illustrated in Figures 4-7. The biomass of undisturbed communities tends to be dominated by slow growing, conservative species with a large body mass ( $\mathrm{K}$ - selected species), but low density. Smaller rapidly growing opportunistic species (r-selected) are more common in disturbed systems. This pattern is visible in Abundance Biomass Comparison curves $(\mathrm{ABC})$ in which the total cumulative abundance and biomass is plotted against species - rank. In undisturbed systems, the biomass line tends to lie above the abundance line, whereas in disturbed systems the situation is reversed. Under moderate pollution, the large competitive dominants are eliminated and the inequality in size between 


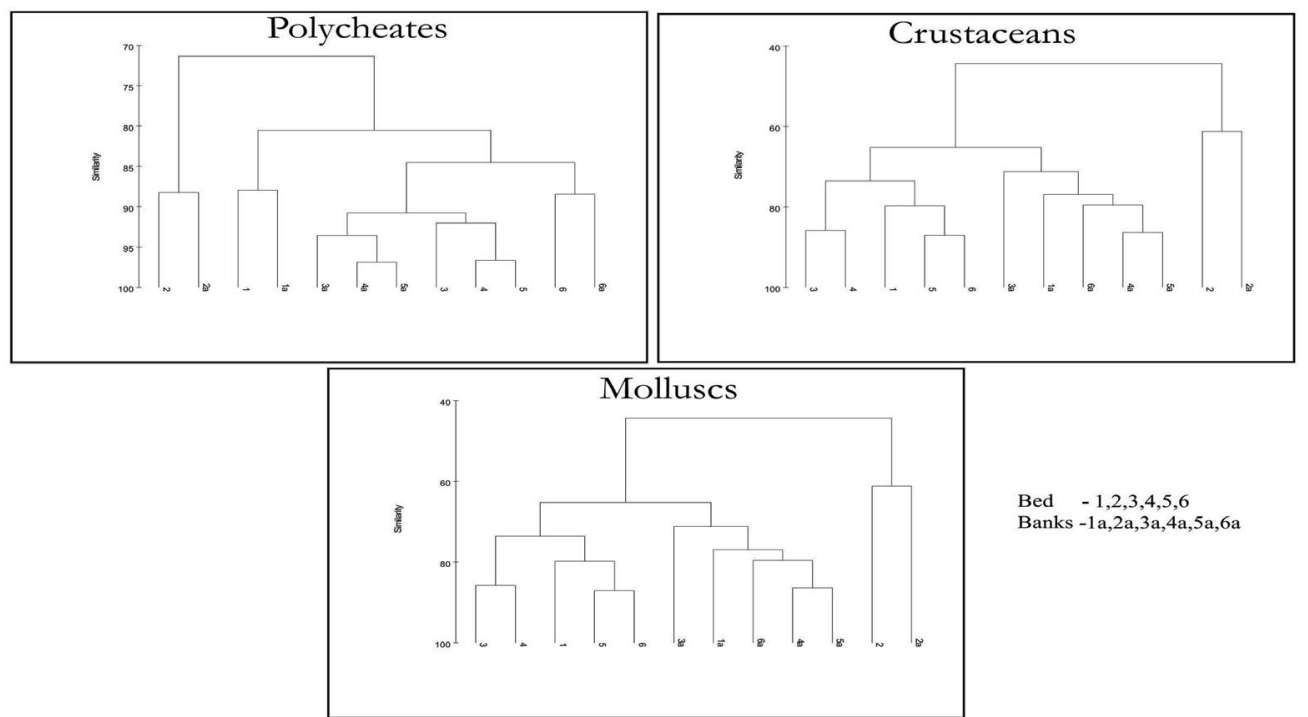

Figure 3) Similarity of stations based on macrofauna abundance.

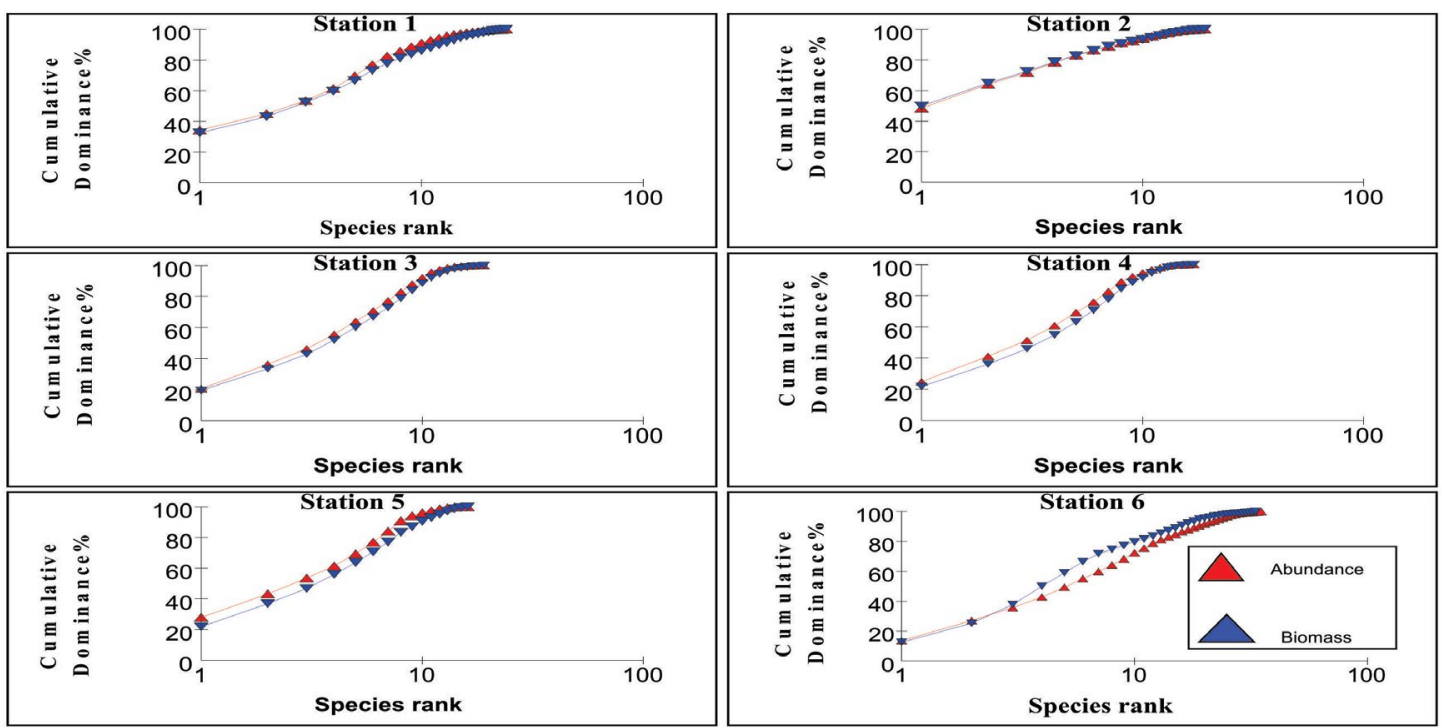

Figure 4) Abundance biomass curve for pre monsoon.

TABLE 3

Macrobenthic biomass.

\begin{tabular}{|c|c|c|c|c|c|}
\hline & Monsoon'04 & Pre monsoon & Post Monsoon & Summer & Monsoon'05 \\
\hline Stations & \multicolumn{5}{|c|}{ Polycheates $\left(\mathbf{g} / \mathrm{m}^{2}\right)$} \\
\hline 1 & 7 & 8 & 7 & 11 & 8 \\
\hline 2 & 21 & 24 & 20 & 29 & 20 \\
\hline 3 & 13 & 14 & 13 & 16 & 12 \\
\hline 4 & 16 & 17 & 15 & 18 & 16 \\
\hline 5 & 12 & 15 & 13 & 16 & 12 \\
\hline \multirow[t]{2}{*}{6} & 7 & 9 & 8 & 10 & 8 \\
\hline & \multicolumn{5}{|c|}{ Crustaceans $\left(\mathrm{g} / \mathrm{m}^{2}\right)$} \\
\hline 1 & 35 & 36 & 34 & 16 & 31 \\
\hline 2 & 14 & 13 & 12 & 8 & 11 \\
\hline 3 & 56 & 48 & 54 & 34 & 59 \\
\hline 4 & 72 & 71 & 74 & 61 & 75 \\
\hline 5 & 148 & 140 & 150 & 104 & 156 \\
\hline \multirow[t]{2}{*}{6} & 150 & 141 & 153 & 100 & 155 \\
\hline & \multicolumn{5}{|c|}{ Molluscs $\left(g / m^{2}\right)$} \\
\hline 1 & 45 & 51 & 41 & 53 & 47 \\
\hline 2 & 31 & 40 & 35 & 47 & 32 \\
\hline 3 & 78 & 96 & 100 & 121 & 81 \\
\hline 4 & 98 & 112 & 131 & 142 & 97 \\
\hline 5 & 123 & 163 & 154 & 185 & 130 \\
\hline 6 & 152 & 181 & 165 & 197 & 158 \\
\hline
\end{tabular}




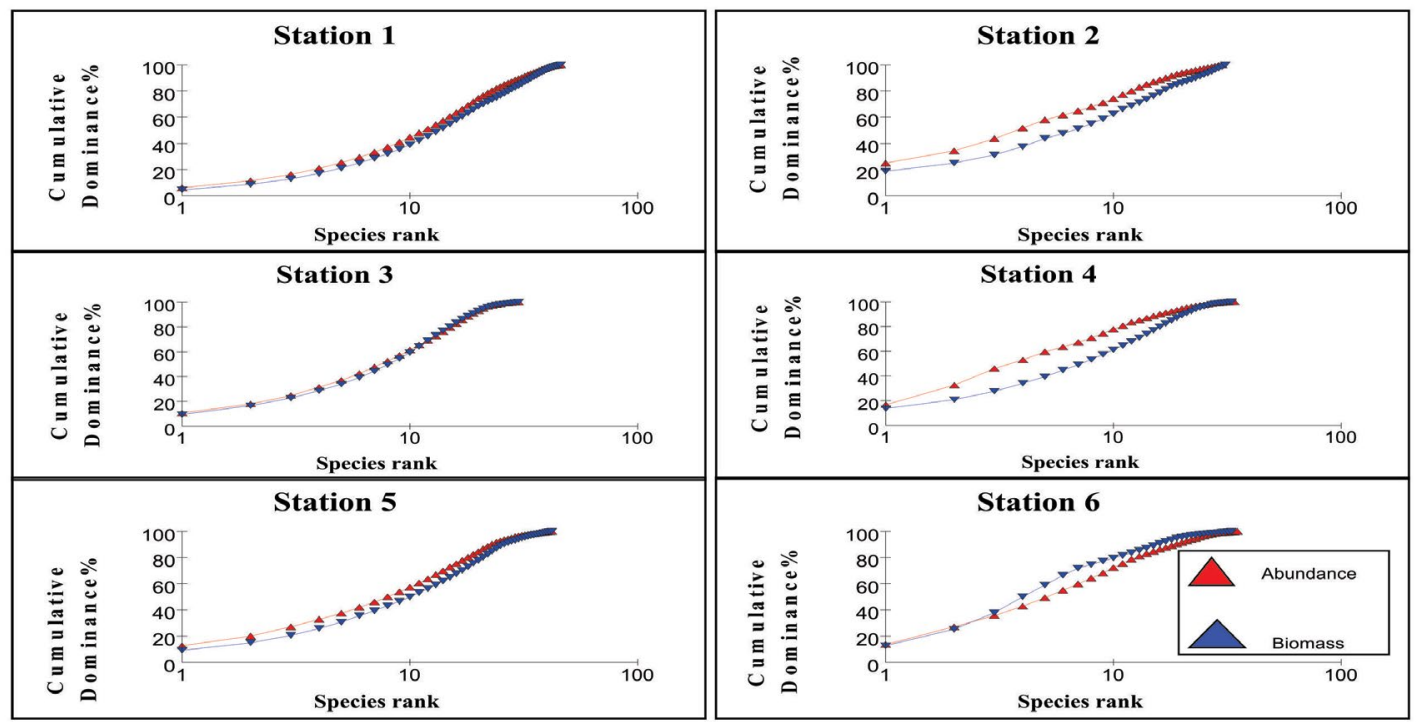

Figure 5) Abundance biomass curve for summer.

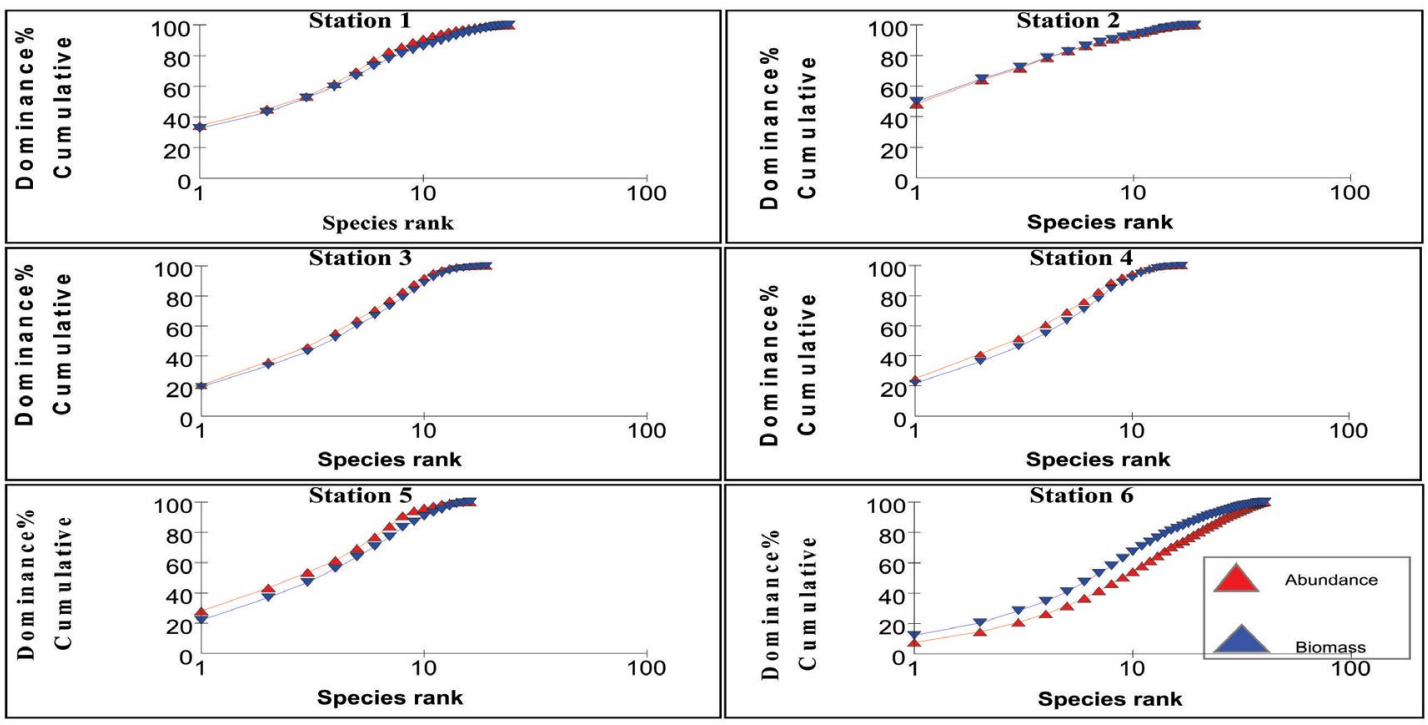

Figure 6) Abundance biomass curve for monsoon.
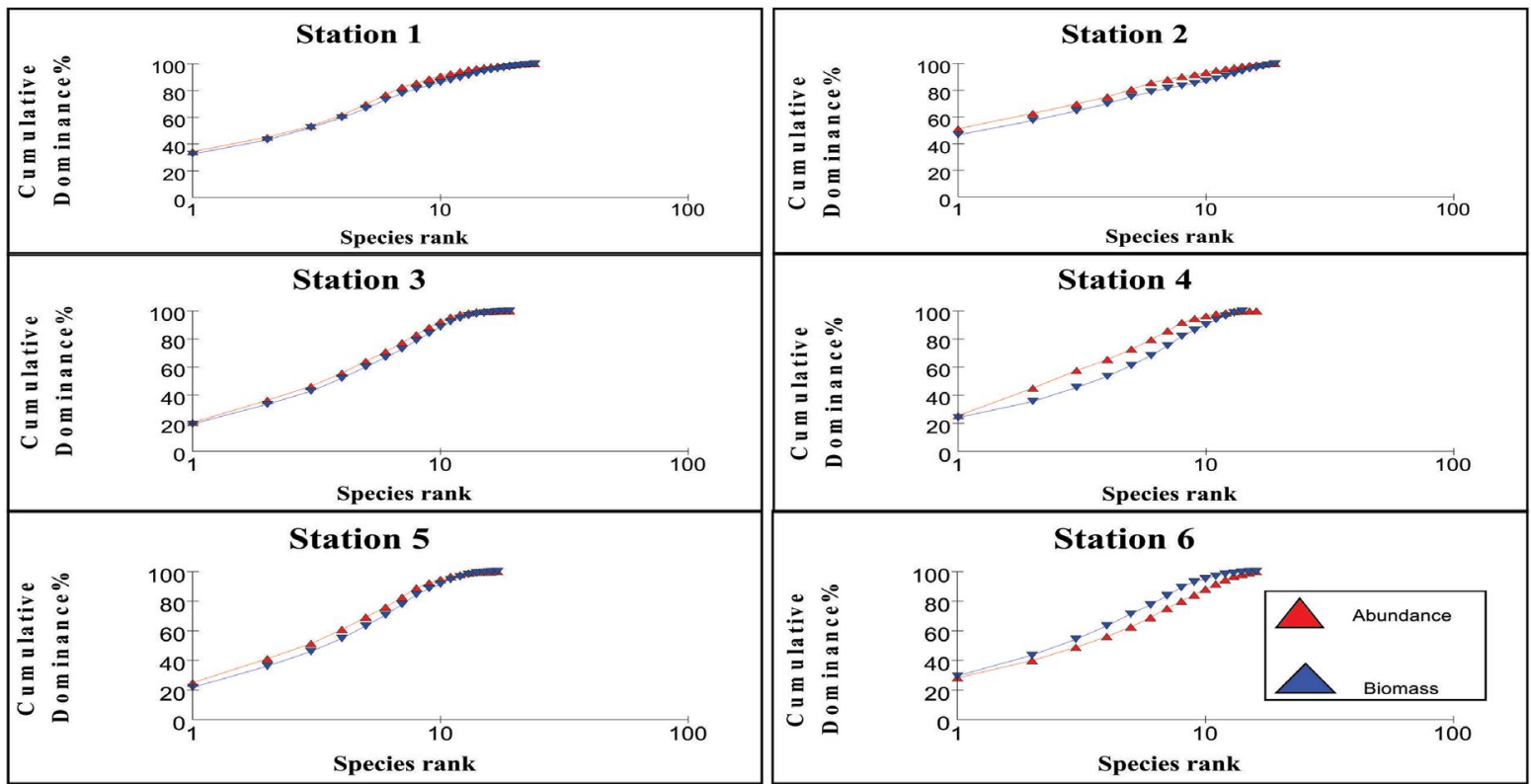

Figure 7) Abundance biomass curve for post monsoon. 
TABLE 4

Discriminating species.

\begin{tabular}{|c|c|c|c|c|}
\hline Species & Av.Sim & Sim/SD & $\begin{array}{l}(\text { Av.Sim)/ } \\
\text { (Sim/SD) }\end{array}$ & Contrib\% \\
\hline \multicolumn{5}{|c|}{ STATION 1} \\
\hline Diopatraneapolitana & 3.31 & 1.53 & 2.16 & 4.25 \\
\hline Nephthys polybranchia & 2.98 & 1.4 & 2.13 & 3.83 \\
\hline Glycera alba & 2.81 & 1.5 & 1.87 & 3.62 \\
\hline Balanusvariegatus & 1.2 & 1 & 1.2 & 3.1 \\
\hline Capitellacapitata & 2.31 & 4.1 & 0.56 & 2.96 \\
\hline Balanusamphitrite & 1.93 & 1.78 & 1.08 & 2.49 \\
\hline \multicolumn{5}{|c|}{ STATION 2} \\
\hline Capitellacapitata & 12.21 & 3.36 & 3.63 & 17.92 \\
\hline Ceratonereis costae & 5.31 & 4.14 & 1.28 & 7.79 \\
\hline Glycera alba & 2.95 & 2.09 & 1.41 & 2.86 \\
\hline Nephthys polybranchia & 1.9 & 1.65 & 1.15 & 2.78 \\
\hline \multicolumn{5}{|c|}{ STATION 4} \\
\hline Capitellacapitata & 5.46 & 4.78 & 1.14 & 5.56 \\
\hline Cossura delta & 3.82 & 3.75 & 1.02 & 4.96 \\
\hline Ancistrosyllisconstricta & 3.14 & 2.8 & 1.12 & 4.07 \\
\hline Glycera alba & 2.98 & 2.11 & 1.41 & 3.87 \\
\hline Marcia opima & 5.78 & 4.78 & 1.2 & 4.23 \\
\hline Scylla serrata & 1.71 & 1.1 & 1.5 & 2.22 \\
\hline Balanusamphitrie & 1.55 & 9.13 & 0.17 & 2 \\
\hline \multicolumn{5}{|c|}{ STATIONS 3 AND 5} \\
\hline Cossura delta & 3.84 & 3.77 & 1.02 & 5.1 \\
\hline Ancistrosyllisconstricta & 3.08 & 2.31 & 1.33 & 4.09 \\
\hline Capitellacapitata & 4.91 & 4.05 & 1.21 & 3.87 \\
\hline Ceretonereis costae & 3.69 & 2.88 & 1.28 & 2.25 \\
\hline Mactraleavis & 2.54 & 2.25 & 1.13 & 2.04 \\
\hline Marcia opima & 3.09 & 3.09 & 1 & 1.93 \\
\hline Scylla serrata & 1.71 & 1.1 & 1.5 & 2.22 \\
\hline Turritellacolumnaris & 2.37 & 2.2 & 1.08 & 3.04 \\
\hline \multicolumn{5}{|c|}{ STATION 6} \\
\hline Cerithideacingulata & 4.21 & 3.34 & 1.26 & 4.16 \\
\hline Meretrixmeretrix & 3.01 & 2.1 & 1.43 & 3.89 \\
\hline Marcia opima & 1.87 & 1.79 & 1.04 & 2.43 \\
\hline Turritellaattenuata & 1.72 & 1.1 & 1.5 & 2.23 \\
\hline Meretrixcasta & 2.55 & 2.39 & 1.07 & 2 \\
\hline Scylla serrata & 5.54 & 4.31 & 1.29 & 3.91 \\
\hline Turritellacolumnaris & 2.37 & 2 & 1.18 & 3.04 \\
\hline
\end{tabular}

Polycheates, Crustaceans, Molluscs

the numerical and biomass dominants is reduced so that the biomass and abundance curves are closely coincident and may cross each other one or more times (25). The contention is that these three conditions polluted, moderately polluted and grossly polluted should be recognizable in a community without reference to control samples in time or space, the two curves acting as an "internal control" against each other.

The $\mathrm{k}$ - dominance curve of the ABC - curves confirmed that in Stations 2 and 4 , the degree of pollution is increasing from post monsoon to summer and decrease in pre monsoon. The dilution due to fresh water mixing leads to less pollution levels in these stations during monsoon. This indicates that the species composition in both the Stations is characterized by several numerically abundant species with relatively low biomasses. The reason for the occurrence of this type of curve is the communities present are composed of r-selected or opportunistic species. This plot showed that Stations 1 5 are characterized by low biomass species with high abundance, proving a disturbed environment. As the two lines intersect for Stations 1, 3 and 5 , it is clear that they are moderately polluted. Irrespective of the seasons, Station 6 has high species density proving it is less polluted. At Station 6, the intersection of these lines to a lesser extent indicate this station is also liable to be polluted in summer and pre monsoon, whereas during monsoon and post monsoon the fresh water addition reduces the pollution load. These observations are very well supported by the physico-chemical and macrofauna analyses of the stations. Coastal ecosystems such as lagoons are often thought of as being fragile and highly productive (33). Due to their hydrological characteristics and environmental conditions, lagoons endure frequent fluctuations on a daily and seasonal basis which causes many changes in the distribution of benthic species and in the structure of communities (34) often aggravated by anthropogenic influences. Because of such ecological characteristics, conflicts will often arise between their exploitation and the protection of natural resources. A sound understanding of their structure and their way of functioning is therefore necessary to implement effective management and conservation measures (35). Yet information about natural temporal variability in lagoons is also very important.

\section{CONCLUSION}

It can be concluded that the abundance and diversity of macrobenthic faunal community of the Ennore creek is significantly influenced by some soil biomantle factors of the existing environment. The Standing Crop of macrofauna shows seasonal fluctuations in the faunal densities, but the variation is less pronounced. Station wise density can be presented as Stations $6>2>4>5>3>1$. The macrofauna distribution, species composition and dominance are closely associated with prevailing hydrographic parameters and nutrients. Higher nutrient concentration during summer coincides with high density of polycheates and molluscs and vice versa during monsoon season. Salinity is also an important factor for macrofauna distribution and growth. Salinity is high during pre-monsoon and summer which resulted in high production. Naturally these organisms are typically stenohaline in nature. The lower population density during monsoon could be attributed to the flow of large quantity of freshwater into the Canal which reduces the salinity. Indiscriminate discharge of untreated municipal, discharge of coolant water and industrial wastes should be minimized or stopped in order 
to save the environment as well as the macro benthic faunal community of Ennore Creek.

\section{REFERENCES}

1. Engle VD, Summers JK, Gaston GR. A benthic index of environmental condition of Gulf of Mexico estuaries. Estuaries 1994;17:372-384.

2. Weisberg SB, Ranasinghe JA, Dauer DM, et al. An estuarine benthic index of biotic integrity (B-IBI) for Chesapeake Bay. Estuaries 1997;20(1): $149-158$.

3. Borja Á, Franco J, Pérez V. A marine biotic index to establish the ecological quality of soft-bottom benthos within european estuarine and coastal environments. Marine Poll Bull 2000;40:1100-1114.

4. Ziglio G, Siligardi M, Flaim G. Biological monitoring of rivers: Chichester. John Wiley \& Sons, New York. 2006:469.

5. MistriM,FanoEA, RossiG, etal. Variabilityin macrobenthos communities in the Valli di Comacchio. Northern Italy, a hypereutrophized lagoonal ecosystem. Estuar. Coast. Shelf Sci 2000;51:599-611.

6. Lardicci C, Como S, Corti S, et al. Recovery of the macrozoobenthic community after severe dystrophic crises in a Mediterranean coastal lagoon (Orbetello Italy). Mar Poll Bull 2001;42:202-14.

7. LakhdarIdrissi J, Orbi A, Zidane F, et al. Organisation et fonctionnement d'un écosystèmecôtier du Maroc : la lagune de Khnifiss. Revue des Sciences de l'Eau 2004;17:447-62.

8. Le Bris H, Glémarec M. Marine and brackish ecosystems of south Brittany (Lorient and Vilaine Bays) with particular reference to the effect of the turbidity maxima. Estuarine and Coastal Shelf Science 1996;42:737-53.

9. Dakki M, Ligny W. The Khnifiss lagoon and its surrounding environment (Province of La'youne, Morocco). Travaux Institut Scientifique de Rabat, Hors-série. 1988:172.

10. NRC (National Research Council). Ecological Indicators for the Nation National Academy Press, Washington, DC. 2000.

11. Marques JC, Salas F, Patrício J, et al. Ecological Indicators for Coastal and Estuarine Environmental Assessment $\square$ A User Guide. WIT PRESS, Southampton, Boston, 2009:183.

12. Fisher WS, Jackson LE, Suter II GW, et al. Indicators for human and ecological risk assessment: A.U.S. Environmental Protection Agency Perspective. Human and Ecological Risk Assessment 2001;7:961-70.

13. Kurtz JC, Jackson LE, Fisher WS. Strategies for evaluating indicators based on guidelines from the Environmental Protection Agency's Office of Research and Development. Ecological Indicators 2001;1:49-60.

14. Young TF, Sanzone S. A framework for assessing and reporting on ecological condition: A SAB report. EPA]SAB[EPEC[02-009. U.S. Environmental Protection Agency, Washington, DC. 2002:142.

15. Niemi GJ, McDonald ME. Application of ecological indicators. Annu Rev Ecol Evol Syst 2004;35:89-111.

16. Salas F, Marcos C, Neto JM, et al. User \friendly guide for using benthic ecological indicators in coastal and marine quality assessment. Ocean \& Coastal Management 2006;49:300-31.

17. Rees HL, Hyland JL, Hylland K, et al. Environmental Indicators: utility in meeting regulatory needs. An overview. ICES Journal of Marine Science 2008;65:1381-1386

18. Marques JC, Salas F, Patrício J, et al. Ecological indicators for coastal and estuarine environmental assessment $\square$ a user guide. WIT PRESS, Southampton, Boston. 2009:183.

19. Fauvel P. The Fauna of India including Pakistan, Ceylon, Burma and Malaya. The Indian Press Ltd, Allahabad. 1953:507-15.

20. Srikrishnadhas B, Murugesan P, Ajmal Khan S. A monograph on the polychaetes of Parangipettai coast. Annamalai University, India. 1998:110.

21. Barnes RD. Invertebrate zoology. Saunders College, Philadelphia. 1980:1089

22. Lyla PS, Velvizhi S, Ajmal Khan S. A monograph on the amphipods of Parangipettai coast. Annamalai University, India. 1999:78.

23. Rajagopal S, Ajmal Khan S, Srinivasan M, et al. A monograph on the gastropods of Parangipettai coast. Annamalai University, India. 1998:38.

24. Shanmugan A, Rajagopal S, Nazeer RA. A monograph on the common bivalves of Parangipettai coast. Annamalai University, India. 1997:66.

25. Draper N, Smith H .Applied regression analysis. John Wiley and Sons, New York. 1981

26. Clarke KR, Warwick RM. Changes in marine communities: an approach to statistical analysis and interpretation. Plymouth Marine Laboratory, Plymouth. 1994.

27. Debasish M, Panigrahy RC, Sudarshan P, et al. Enfluence of monsoon on macrobenthic assemblage in outer channel area of Chilika lagoon of East coast of India. J of Wetlands Ecology 2009;3:56- 67.

28. Bhat UG, Neelakantan. Environmental impact of macrobenthos distribution of Kali estuary, Central west coast of India. Ind J of Mar Sci $1988 ; 17: 134-142$

29. Commito JA, Ambrose WG. Multiple trophic levels in soft bottom communities. Marine Ecology-Progress Series 1985;26:289-93.

30. McIntyre AD. Ecology of marine meiobenthos. Biol Rev. 1968;44:245290.

31. Dviwedi SN, Rahim A, Nair SA. Ecology and production of intertidal sand fauna during southwest monsoon along Mandovi estuary (Goa). In recent researches in estuarine Biology. Hindustan publishing Corporation, Delhi. 1975:1-20.

32. Sreeramamurthy KB. Ecology of intertidal macrofauna at Versova and seven Bungalows Beaches, Bombay. M.Sc. Desertion, University of Bombay, Bombay. 1980:67-73.

33. Artemis N, Petrou K, Kormas K A, et al. Inter-annual variability of soft bottom macrofaunal communities in two Ionian Sea lagoons. Hydrobiologia 2006;555:89-98.

34. Millet B, Guelorget O. Spatial and seasonal variability in the relationships between benthic communities and physical environment in a lagoon ecosystem. Marine Ecology Progress Series 1994;108:161-174.

35. Amanieu M, Ferraris J, Guélorget O. Organisationetévolution des peuplements des laguneslittorales. Application à la macrofaunebenthique des étangspalavasiens. Recherchesd'écologiethéorique. Les stratégiesadaptatives. (Maloined). 1980. 